REVIEW

\title{
Tongue carcinoma in young adults: a review of the literature
}

\author{
Il carcinoma della lingua nei giovani: revisione della letteratura
}

\author{
A. PADERNO'1, R. MORELLO'1, C. PIAZZA² \\ ${ }^{1}$ Department of Otolaryngology, Head and Neck Surgery, University of Brescia, Italy; ${ }^{2}$ Department of Otolaryngology, \\ Head and Neck Surgery, Fondazione IRCCS, Istituto Nazionale dei Tumori di Milano, University of Milan, Italy
}

\section{SUMMARY}

A recent reduction in the number of smoke-related tumours has been observed thanks to the diffusion of anti-tobacco campaigns carried out in the majority of developed countries. Nevertheless, as demonstrated by recent global epidemiologic studies, squamous cell carcinoma of the mobile tongue appears to be progressively increasing in incidence, particularly among young adults and especially in females. The driving mechanism responsible for such changes is still to be precisely defined. Several genetic studies have compared the mutational pattern of tongue squamous cell carcinoma in young adults to that of more elderly patients, without identifying significant differences that may help in better characterising this subgroup of subjects. Tongue squamous cell carcinomas in young adults have been historically considered as particularly aggressive clinical entities, with a high risk of loco-regional relapse, survival rates inferior to those of the general head and neck cancer group and need for a more aggressive therapy. However, considering the most recent studies, prognostic results in this patient group are heterogeneous and it is not possible to confirm this tendency. Thus, it is not justified to embrace different therapeutic approaches according to patient age. Eventually, an additional element to consider when examining young subjects affected by tongue cancer is the possibility of genetic predisposition. Alterations affecting pathways involved in DNA repair, surveillance of genetic stability or regulation of cellular growth may determine an increased likelihood of developing head and neck cancers.

KEY WORDS: Tongue carcinoma $\bullet$ Young $\bullet$ Epidemiology $\bullet$ Prognosis $\bullet$ Therapeutic approach

\section{RIASSUNTO}

Grazie alla diffusione delle campagne anti-fumo che sono state portate avanti dalla maggior parte delle nazioni sviluppate, negli ultimi anni è stata osservata una riduzione del numero dei tumori ad esso correlati. Ciononostante, come dimostrato da recenti studi epidemiologici mondiali, l'incidenza dei carcinomi squamosi della porzione mobile della lingua è progressivamente aumentata, in particolare nei giovani e specialmente nelle donne. Il meccanismo responsabile di questi cambiamenti epidemiologici non è ancora stato precisamente definito. Diversi studi genetici hanno confrontato il pattern mutazionale dei carcinomi squamocellulari dei giovani rispetto a quelli dei soggetti più anziani, senza identificare differenze significative che permettano una migliore caratterizzazione di questo sottogruppo di pazienti. Storicamente, il carcinoma squamocellulare nei giovani è stato considerato come un'entità clinica particolarmente aggressiva, con un rischio maggiore di recidiva loco-regionale ed un tasso di sopravvivenza inferiore rispetto alla popolazione generale dei pazienti con carcinomi testa e collo, che necessiterebbe di trattamenti più aggressivi. Considerando i più recenti studi, i risultati prognostici di questo gruppo di pazienti sono eterogenei e non è possibile confermare tale tendenza. Non sembra quindi al momento giustificato un approccio terapeutico differenziato in base all'età del paziente. Un altro elemento da prendere infine in considerazione quando si valutano pazienti affetti da carcinoma della lingua in giovane età è la possibile presenza di una predisposizione genetica. Mutazioni che interessano i sistemi di riparazione del DNA, la sorveglianza della stabilità genetica o la regolazione della crescita cellulare possono determinare un aumento della probabilità di sviluppare un carcinoma del distretto testa-collo in giovane età.

PAROLE CHIAVE: Carcinoma della lingua $\bullet$ Giovani $\bullet$ Epidemiologia $\bullet$ Prognosi $\bullet$ Approccio terapeutico

Acta Otorhinolaryngol Ital 2018;38:175-180

\section{Introduction}

Head and neck tumours are typically characterised by a peak of incidence in the elderly and a strong correlation with chronic exposure to risk factors such as smoking and alcohol abuse ${ }^{1}$. This is a consequence of the typical pattern of initiation and neoplastic progression which is encountered in these anatomical sites, characterised by an incremental accumulation of mutations leading, in 
the long-run, to frank neoplastic transformation ${ }^{2}$. In this sense, the adult-elderly age has a central role in allowing the accumulation of a sufficient rate of genetic alterations to promote carcinogenesis ${ }^{34}$.

Nevertheless, around 5\% of patients suffering from head and neck cancer are diagnosed before they reach the age of 45 years. The incidence in this subgroup appears to be consistently growing, a trend that is in contrast to what observed in the general population. This phenomenon seems to be mainly linked to an increase of oropharyngeal carcinomas (mainly human papilloma virus [HPV]related) and of the oral cavity (apparently not related to any known virus), paralleled by a reduction of laryngeal and hypopharyngeal tumours ${ }^{5}$.

The aim of this review is to collect evidence published in the recent literature and pertinent to such an epidemiological trend, with special emphasis on oral tongue squamous cell carcinoma (SCC) in the young population. Due to the remarkable heterogeneity of studies assessing the molecular, epidemiological and clinical characteristics of tongue SCC, a non-structured review on all evidence available to date will be presented for each of these aspects.

\section{Epidemiology}

In oral cavity SCCs, gender distribution is different according to the age of onset taken into consideration: while in the elderly, males represent over $70 \%$ of cases, this percentage falls to $50-65 \%$ under 45 years of age. This difference has increased evidence when considering that the majority of non-smokers and non-drinkers young patients are females ${ }^{67}$. These epidemiological features may thus represent the expression of aetiopathogenic differences distinguishing the young subgroup of patients from the elderly.

Thanks to the diffusion of anti-tobacco campaigns carried out in the majority of developed countries, it has been possible to observe a recent reduction in the number of smoke-related tumours. Nevertheless, oral cavity SCC, in particular of the mobile tongue, as well as those of the oropharynx, appear to have a progressively increasing incidence ${ }^{8}$. While in oropharyngeal carcinomas this may be explained by an increasing exposure to the HPV, in the oral cavity, a specific pathogenic role for viral infections has yet to be demonstrated ${ }^{9-11}$.

Tongue SCCs demonstrate an increasing incidence in the young population, as previously reported in the 1990s by a group of American authors ${ }^{12-14}$. These data were further confirmed by a global study specifically investigating tongue carcinomas and including a total of 22 tumour registries. This study highlighted a yearly increase ranging from $0.4 \%$ to $3.3 \%$ that was significantly higher in young patients ( $<45$ years) in 14 out of 22 registries ${ }^{8}$. In this comprehensive analysis, the greatest increase observed in females, particular in the younger cohort, was found only in some registries, while in others a homogenous distribution or even a male preponderance was shown 269101415 . In this context, it is however important to point out the difficulties in sorting out precise data for particular subgroups with homogenous clinical characteristics. Considering these recent epidemiological changes, some authors have hypothesised the involvement of a viral agent in the carcinogenetic process which may be known or yet to be defined, even though no specific viral genetic material has been consistently isolated in tongue SCCs of young patients ${ }^{1617}$.

\section{Peculiarities of tongue tumours in young adults}

From a clinical standpoint, tongue SCCs in the under-45 year-old group, particularly if non-smokers and non-drinkers, are found to prevalently originate from the tongue edge ${ }^{16}$. The concept of "field cancerisation", typically seen in the general head and neck cancer group, in these patients appears less evident, with a pattern of relapse/second tumour generally characterised by the involvement of the residual tongue in continuity with the primary neoplastic lesion ${ }^{16} 1819$. However, no evidence of differences in histopathological features have been reported ${ }^{20}$. Some authors have also described the relapse tendency in the first two years of follow-up, with a significant decrease in risk following this lapse of time ${ }^{21}$.

Considering the varied epidemiological characteristics, some genetic studies have compared the mutational pattern of tongue SCCs in young adults to that of more elderly patients. In the vast majority of publications, the two types of tumours have been shown to be similar and generally comparable to head and neck carcinomas ${ }^{22}$. The most frequently mutated genes have been reported to be TP53, CDKN2A, NOTCH1, CASP8, FAT1, PIK3CA and MLL2 in both groups of patients ${ }^{23}$. In the literature, however, heterogeneous results have been reported in relation to the prevalence of p53 mutations in young patients, with a tendency to a significant increase in some studies ${ }^{23}$ and a decrease in others, in particular for non-smokers ${ }^{24}{ }^{25}$. A recent analysis performed by Knopf and colleagues ${ }^{26}$ has shed further light on the molecular mechanisms linked to the starting of tongue SCCs in patients below 45 years of age, highlighting a predominant alteration of the WNTCTNNB1-STK11 and CDKN2A-HGF-MET pathways, as well as increased expression of ATM, BRCA1, E2F1, 
and FHIT. Such a biological molecular landscape may be associated with greater radio-sensitivity in this patient population, which has significant consequences from the therapeutic and prognostic points of view ${ }^{27-30}$.

However, these differences in genes mutation/expression may be mainly related to heterogeneous study populations: when analysing the extensive "The Cancer Genome Atlas" (TCGA) database, it is not possible to confirm any significant difference in relation to age, even considering the most recent genomic data ${ }^{31} 32$. Thus, tongue SCC in young patients appears to be comparable to those in elderly patients even when taking into account their genetic alterations.

\section{Prognosis}

Historically, tongue SCCs in young adults have been considered by many authors as particularly aggressive clinical entities, with a high risk of loco-regional relapse, and survival rates inferior to that of the general population and resulting need for a more aggressive course of therapy ${ }^{12} 33-35$. However, considering the most recent studies, the prognostic results in this patient group are heterogeneous and it is not possible to confirm this tendency $121319243335-41$. This heterogeneity of results may also depend on the variable definition of "young age", with a wide range of cut-offs going from 30 to 45 years of age. In the future, to make the data more homogeneous and comparable, it has been suggested that it might be useful to consider as young patients only those below the age of $30^{42}$. In the specific field of tongue SCCs, the analysis of a wide case series of 276 patients ( 66 below and 210 over the age of 45) performed by Knopf and colleagues ${ }^{26}$ has revealed a significant prognostic advantage in younger patients. Regardless of this consideration, it is crucial to interpret this result as likely influenced by tumour extension, and thus $\mathrm{T}$ category, which is significantly lower in patients below 45 years of age (without differences in $\mathrm{N}$ and $\mathrm{M}$ categories). This selection bias is partly mitigated by case-matched studies characterised by a homogenous patient distribution in relation to tumour characteristics and comorbidities. Considering these types of studies, a broad cohort of 185 patients below the age of 45 affected by head and neck SCC, 80 of which of the oral cavity, compared with an analogous group of elderly subjects, demonstrated better results in terms of overall survival and second tumour occurrence in young patients ${ }^{13}$. Focusing the analysis on tongue carcinomas, 20 cases under- 45 years compared with the same number of older subjects, matched by stage and gender, highlighted better overall and disease-related survivals in the younger subgroup ${ }^{43}$.
On the other hand, some studies have demonstrated the absence of prognostically significant differences, taking into account 87 patients $\leq 45$ years of age in a study by Lassig and colleagues ${ }^{44}$ and 31 patients $\leq 40$ years analysed by Pytynia and coworkers ${ }^{45}$, both case-matched and including head and neck tumours in general. Finally, Blanchard and co-authors ${ }^{46}$ have recently confirmed the absence of significant differences in 50 patients $\leq 40$ years affected by tongue carcinomas versus older subjects matched by stage at presentation. It is nevertheless important to point out the outlier results on tongue SCC reported by at least three different studies ${ }^{47-49}$, which showed a significant increase of relapses in young adults and a related negative impact on overall survival within this cohort. A nonsignificant trend towards poorer prognosis has also been reported by the group led by Kourelis ${ }^{50}$ which considered only patients with early stage tongue SCCs. In particular, in young women, there has also been evidence of a significant increase in the risk of relapse compared to matched cases ${ }^{50}$.

\section{Genetically-determined conditions of increased susceptibility to tongue cancer}

An additional element to take into consideration when examining patients affected by tongue SCC in the young age is the possibility of some sort of genetic predisposition ${ }^{2}$. Alterations affecting pathways involved in DNA repair, surveillance of genetic stability or regulation of cellular growth may determine an increased likelihood of developing head and neck cancers. This is clearly exemplified in rare hereditable syndromes linked to specific genetic mutations leading to a dramatically increased incidence of head and neck cancers and tumours in general. These are represented, in particular, by Fanconi anaemia, xeroderma pigmentosum, Bloom, Li-Fraumeni, familial atypical multiple mole melanoma, and ataxia telangiectasia syndromes. In all these diseases, the increased risk in developing tongue SCC (that may reach an incidence up to 700-1000 greater than that for the general population) can be associated with that reported for other neoplasms and syndromic presentations. The suspicion of a geneticallydetermined alteration should arise from a detailed family history of the proband positive for: 1) first-degree relative with the same kind of tumour and same clinical presentation; 2) two or more first-degree relatives with a tumour in the same location; 3 ) two or more first-degree relatives affected by rare tumours.

It is, however, important to note the existence of increased susceptibility to head and neck cancers even in the absence of syndromic presentations. Retrospective studies 
have, in fact, demonstrated a relative risk that is increased 3.6-fold in subjects with first-degree relatives affected by other head and neck cancers ${ }^{51-53}$. In addition, young adults affected by tumours in these locations have been shown to be increasingly susceptible to genotoxic stress as shown by the bleomycin test, strongly suggesting the development of an increased number of chromosomal alterations in respect to older subjects ${ }^{53}$. In a similar manner, young adults affected by such neoplasms have shown an increased vulnerability to the negative effects of smoking (compared to healthy volunteers), a feature likely linked to an increased prevalence in this population of single nucleotide polymorphisms in genes involved in the repair of alcohol- and smoke-related mutations and in regulation of the cell cycle ${ }^{54-56}$.

\section{Conclusions}

Tongue SCC in young adults represents a rare disease, characterised by an incidence that has been recently reported as increasing, particularly in females. However, no specific aetiopathogenic agent has been identified to date that may provide a univocal explanation for such a trend. As of today, it is not possible to demonstrate significant differences with respect to the general head and neck cancer patients group in terms of prognosis and, thus, a comprehensive therapeutic approach according to current guidelines should be recommended. In this view, thanks to the overall fitness of young patients, the "optimal treatment" according to tumour stage and characteristics may be frequently obtained, while it is essential to avoid unjustified overtreatments on the basis of patient's age alone.

In consideration of the patients' life expectancy, functional impairment and risk of recurrence, a long-lasting follow-up should be considered, with the aim of allowing an early diagnosis of persistent/recurrent disease, monitoring and optimising the patient's quality of life, and promoting awareness of adjunctive risk factors such as tobacco or alcohol consumption.

Patients presenting with associated syndromic characteristics, a suggestive family history and age of onset below 20-30 years might also require detailed genetic counselling to better assess the general disease framework.

\section{References}

1 Sankaranarayanan R, Masuyer E, Swaminathan R, et al. Head and neck cancer: a global perspective on epidemiology and prognosis. Anticancer Res 1998;18:4779-86.

2 van Monsjou HS, Wreesmann VB, van den Brekel MWM, et al. Head and neck squamous cell carcinoma in young patients. Oral Oncol 2013;49:1097-102.
3 Pai SI, Westra WH. Molecular pathology of head and neck cancer: implications for diagnosis, prognosis, and treatment. Annu Rev Pathol 2009;4:49-70.

4 Stadler ME, Patel MR, Couch ME, et al. Molecular biology of head and neck cancer: risks and pathways. Hematol Oncol Clin North Am 2008;22:1099-124.

5 Siegel RL, Miller KD, Jemal A. Cancer statistics. CA Cancer J Clin 2016;66:7-30.

6 Harris SL, Kimple RJ, Hayes DN, et al. Never-smokers, never-drinkers: unique clinical subgroup of young patients with head and neck squamous cell cancers. Head Neck 2010;32:499-503.

7 Hussein AA, Helder MN, de Visscher JG, et al. Global incidence of oral and oropharynx cancer in patients younger than 45 years versus older patients: a systematic review. Eur J Cancer 2017;82:115-27.

$8 \mathrm{Ng} \mathrm{JH}$, Iyer NG, Tan M-H, et al. Changing epidemiology of oral squamous cell carcinoma of the tongue: a global study. Head Neck 2017;39:297-304.

9 Auluck A, Hislop G, Bajdik C, et al. Trends in oropharyngeal and oral cavity cancer incidence of human papillomavirus (HPV)-related and HPV-unrelated sites in a multicultural population: the British Columbia experience. Cancer 2010;116:2635-44.

10 Poling JS, Ma X-J, Bui S, et al. Human papillomavirus $(H P V)$ status of non-tobacco related squamous cell carcinomas of the lateral tongue. Oral Oncol 2014;50:306-10.

11 Kabeya M, Furuta R, Kawabata K, et al. Prevalence of human papillomavirus in mobile tongue cancer with particular reference to young patients. Cancer Sci 2012;103:161-8.

12 Sarkaria JN, Harari PM. Oral tongue cancer in young adults less than 40 years of age: rationale for aggressive therapy. Head Neck 1994;16:107-11.

13 Verschuur HP, Irish JC, O'Sullivan B, et al. A matched control study of treatment outcome in young patients with squamous cell carcinoma of the head and neck. Laryngoscope 1999;109:249-58.

14 Patel SC, Carpenter WR, Tyree S, et al. Increasing incidence of oral tongue squamous cell carcinoma in young white women, age 18 to 44 years. J Clin Oncol 2011;29:1488-94.

15 Beena V, Chauhan I, Heera R, et al. Oral cancer in young non-habitué females: a report of four cases and review of the literature. Aust Dent J 2011;56:322-7.

16 Li R, Faden DL, Fakhry C, et al. Clinical, genomic, and metagenomic characterization of oral tongue squamous cell carcinoma in patients who do not smoke. Head Neck 2015;37:1642-9.

17 Brägelmann J, Dagogo-Jack I, El Dinali M, et al. Oral cavity tumors in younger patients show a poor prognosis and do not contain viral RNA. Oral Oncol 2013;49:525-33.

18 Fang Q-G, Shi S, Liu F-Y, et al. Tongue squamous cell carcinoma as a possible distinct entity in patients under 40 years old. Oncol Lett 2014;7:2099-102.

19 Siegelmann-Danieli N, Hanlon A, Ridge JA, et al. Oral tongue cancer in patients less than 45 years old: institutional 
experience and comparison with older patients. J Clin Oncol 1998;16:745-53.

20 Troeltzsch M, Knösel T, Eichinger C, et al. Clinicopathologic features of oral squamous cell carcinoma: do they vary in different age groups? J Oral Maxillofac Surg 2014;72:1291-300.

21 Blanchard P, Belkhir F, Temam S, et al. Outcomes and prognostic factors for squamous cell carcinoma of the oral tongue in young adults: a single-institution case-matched analysis. Eur Arch Otorhinolaryngol 2017;274:1683-90.

22 Kandoth C, McLellan MD, Vandin F, et al. Mutational landscape and significance across 12 major cancer types. Nature 2013;502:333-9.

23 Pickering CR, Zhang J, Neskey DM, et al. Squamous cell carcinoma of the oral tongue in young non-smokers is genomically similar to tumors in older smokers. Clin Cancer Res 2014;20:3842-8.

24 Atula S, Grénman R, Laippala P, et al. Cancer of the tongue in patients younger than 40 years. A distinct entity? Arch Otolaryngol Head Neck Surg 1996;122:1313-9.

25 Lingen MW, Chang KW, McMurray SJ, et al. Overexpression of p53 in squamous cell carcinoma of the tongue in young patients with no known risk factors is not associated with mutations in exons 5-9. Head Neck 2000;22:328-35.

26 Knopf A, Lempart J, Bas M, et al. Oncogenes and tumor suppressor genes in squamous cell carcinoma of the tongue in young patients. Oncotarget 2015;6:3443-51.

27 Sankunny M, Parikh RA, Lewis DW, et al. Targeted inhibition of ATR or CHEK1 reverses radioresistance in oral squamous cell carcinoma cells with distal chromosome arm $11 q$ loss. Genes Chromosomes Cancer 2014;53:129-43.

28 Mansour WY, Bogdanova NV, Kasten-Pisula U, et al. Aberrant overexpression of miR-421 downregulates ATM and leads to a pronounced DSB repair defect and clinical hypersensitivity in SKX squamous cell carcinoma. Radiother Oncol 2013;106:147-54.

29 Joo Y-H, Park S-W, Jung S-H, et al. Recurrent loss of the FHIT gene and its impact on lymphatic metastasis in early oral squamous cell carcinoma. Acta Otolaryngol 2013;133:992-9.

${ }^{30}$ Lee SH, Koo BS, Kim JM, et al. Wnt/ $\beta$-catenin signalling maintains self-renewal and tumourigenicity of head and neck squamous cell carcinoma stem-like cells by activating Oct4. J Pathol 2014;234:99-107.

31 Cerami E, Gao J, Dogrusoz U, et al. The cBio cancer genomics portal: an open platform for exploring multidimensional cancer genomics data. Cancer Discov 2012;2:401-4.

32 Gao J, Aksoy BA, Dogrusoz U, et al. Integrative analysis of complex cancer genomics and clinical profiles using the cBioPortal. Sci Signal 2013;6:11.

33 Friedlander PL, Schantz SP, Shaha AR, et al. Squamous cell carcinoma of the tongue in young patients: a matched-pair analysis. Head Neck 1998;20:363-8.

${ }^{34}$ Goldstein DP, Irish JC. Head and neck squamous cell carcinoma in the young patient. Curr Opin Otolaryngol Head Neck Surg 2005;13:207-11.
35 Randall CJ, Shaw HJ. Malignant tumours of the tongue in young adults. Experience of a secondary referral centre. J Laryngol Otol 1986;100:1295-8.

36 Shiboski CH, Schmidt BL, Jordan RCK. Tongue and tonsil carcinoma: increasing trends in the U.S. population ages 2044 years. Cancer 2005; 103:1843-9.

37 Manuel S, Raghavan SK, Pandey M, et al. Survival in patients under 45 years with squamous cell carcinoma of the oral tongue. Int J Oral Maxillofac Surg 2003;32:167-73.

38 Llewellyn CD, Linklater K, Bell J, et al. Squamous cell carcinoma of the oral cavity in patients aged 45 years and under: a descriptive analysis of 116 cases diagnosed in the South East of England from 1990 to 1997. Oral Oncol 2003;39:106-14.

39 Depue RH. Rising mortality from cancer of the tongue in young white males. N Engl J Med 1986;315:647.

40 Lund VJ, Howard DJ. Head and neck cancer in the young: a prognostic conundrum? J Laryngol Otol 1990;104:544-8.

41 Clarke RW, Stell PM. Squamous carcinoma of the head and neck in the young adult. Clin Otolaryngol Allied Sci 1992; 17:18-23.

42 Zhang Y-Y, Wang D-C, Su J-Z, et al. Clinicopathological characteristics and outcomes of squamous cell carcinoma of the tongue in different age groups. Head Neck 2017;39:2276-82.

43 Lee C-C, Ho H-C, Chen H-L, et al. Squamous cell carcinoma of the oral tongue in young patients: a matched-pair analysis. Acta Otolaryngol 2007;127:1214-7.

44 Lassig AAD, Lindgren BR, Fernandes $\mathrm{P}$, et al. The effect of young age on outcomes in head and neck cancer. Laryngoscope 2013;123:1896-902.

45 Pytynia KB, Grant JR, Etzel CJ, et al. Matched analysis of survival in patients with squamous cell carcinoma of the head and neck diagnosed before and after 40 years of age. Arch Otolaryngol Neck Surg 2004;130:869.

46 Blanchard P, Belkhir F, Temam S, et al. Outcomes and prognostic factors for squamous cell carcinoma of the oral tongue in young adults: a single-institution case-matched analysis. Eur Arch Otorhinolaryngol 2017;274:1683-90.

47 Garavello W, Spreafico R, Gaini RM. Oral tongue cancer in young patients: a matched analysis. Oral Oncol 2007;43:894-7.

48 Hilly O, Shkedy Y, Hod R, et al. Carcinoma of the oral tongue in patients younger than 30 years: comparison with patients older than 60 years. Oral Oncol 2013;49:987-90.

49 Park J-O, Sun D-I, Cho K-J, et al. Clinical outcome of squamous cell carcinoma of the tongue in young patients: a stagematched comparative analysis. Clin Exp Otorhinolaryngol 2010;3:161.

50 Kourelis K, Tsue T, Girod D, et al. Negative prognostic factors for head and neck cancer in the young. J BUON 2013;18:459-64.

51 Foulkes WD, Brunet JS, Kowalski LP, et al. Family history of cancer is a risk factor for squamous cell carcinoma of the head and neck in Brazil: a case-control study. Int J Cancer 1995;63:769-73. 
A. Paderno et al.

52 Copper MP, Jovanovic A, Nauta JJ, et al. Role of genetic factors in the etiology of squamous cell carcinoma of the head and neck. Arch Otolaryngol Head Neck Surg 1995;121:157-60.

53 Cloos J, Reid CB, van der Sterre ML, et al. A comparison of bleomycin-induced damage in lymphocytes and primary oral fibroblasts and keratinocytes in 30 subjects. Mutagenesis 1999;14:87-93.

54 Matlashewski G, Banks L, Storey A, et al. Role of a p53 polymorphism in the development of human papillomavirusassociated cancer. Nature 1998;393:229-34.

55 Jefferies S, Foulkes WD. Genetic mechanisms in squamous cell carcinoma of the head and neck. Oral Oncol 2001;37:115-26.

56 Sturgis EM, Wei Q. Genetic susceptibility molecular epidemiology of head and neck cancer. Curr Opin Oncol 2002; $14: 310-7$.

Received: September 5, 2017 - Accepted: January 9, 2018

Address for correspondence: Cesare Piazza, Department of Otolaryngology, Head and Neck Surgery, Fondazione IRCCS, Istituto Nazionale dei Tumori di Milano, University of Milan, via Giacomo Venezian 1, 20133 Milan, Italy. E-mail: ceceplaza@libero.it; cesare.piazza@istitutotumori.mi.it 